\title{
PENGGUNAAN MODEL PEMBELAJARAN KOOPERATIF TIPE STUDENT TEAMS ACHIEVEMENT DIVISION (STAD) DALAM UPAYA MENINGKATKAN KEMAMPUAN KOMUNIKASI MATEMATIS PADA POKOK BAHASAN PECAHAN
}

\author{
Sri Apiyati \\ sriapiyati@yahoo.co.id \\ PGSD STKIP Sebelas April Sumedang
}

\begin{abstract}
ABSTRAK
Penulis melaksanakan penilitian ini dilatarbelakangi oleh rendahnya kemampuan komunikasi matematis siswa, guru perlu menciptakan formulasi khusus dalam merancang suatu strategi, metode, teknik dan media yang efektif untuk meningkatkan kemampuan komunikasi matematis siswa. Salahsatu upaya yang dapat dilakukan adalah menggunakan model pembelajaran kooperatif tipe student teamachievment division (STAD) dalam upaya meningkatkan kemampuan komunikasi matematis. Penelitian ini menggunakan metode penelitian tindakan (PTK) terhadap semua kelas IV SD Kirisik yang berjumlah 20 Siswa. Data penelitian ini dikumpulkan melalui tes formatif yang digunakan untuk memperoleh gambaran langsung mengenai kemampuan komunikasi matematis, tes subsmatif untuk mengetahui tingkat pemahaman siswa, dan angket untuk memperoleh respon siswa terhadap pelaksanaan pembelajaran. Anggapan dasar yang menjadi acuan dalam penelitian ini adalah guru mampu melaksankan pembelajaran kooperatif tipe student team achievmen division (STAD) pada pokok bahasan pecahan, penggunaan model pembelajaran kooperatif tipe student team achievmen division (STAD) cocok untuk pokok bahasan pecahan, soal yang digunakan diambil dari bab soal dan sudah di sahkan oleh pembimbing. Dari hasil penelitian tes formatif I, II dan III diketahui kemampuan komunikasi matematis siswa meningkat dilanjutkan dengan tes subsumatif setelah dilakukan perhitungan diperoleh hasil akhir 7,0 dengan kriteria cukup, sedangkan hasil pengolahan data angket, nilai rata-rata yang diperoleh sebesar 4,0 yang berkategori positif, jadi dapat disimpulkan bahwa penggunaan model pembelajaran kooperatif tipe student team achievmen division (STAD) berpengaruh pada peningkatan kemampuan komunikasi matematis, materi pemecah dapat dipahami dengan baik dan tanggapan siswa terhadap model pembelajarankooperatif tipe student team achievmen division (STAD)menunjukan sikap yang positif.
\end{abstract}

Kata Kunci : Model Kooperatif, Model STAD, dan Komunikasi Matematis. 


\section{Pendahuluan}

Seiring dengan kemajuan ilmu pengetahuan dan persaingan hidup yang semakin meningkat, manusia berlombalomba untuk menciptakan inspirasi baru sehingga dapat mengubah pola piker masyarakat untuk dapat lebih baik. Diantara semakin banyak mata pelajaran di sekolah, matematika merupakan salah satu mata pelajaran yang masih dianggap sukar,sulit,rumit,dan menakutkan bagi siswa. Hal itu merupakan tantangan bagi guru untuk mengemas proses belajar mengajar dengan mencari salah satu model yang tepat, agar dapat menghilangkan perasaan siswa yang selalu takut dan jenuh terhadap pembelajaran matematika.

Bagi sebagian besar siswa , pembelajaran matematika merupakan salah satu mata pelajaran yang amat berat dan sulit mereka beranggapan bahwa untuk mendapatkan nilai cukup, mereka harus belajar ekstra keras. Hal ini membuat mereka takut terhadap matematika dan sekaligus malas untuk mempelajarinya. Berdasarkan hasil penelitian, hal ini dikarenakan rendah nya penalaran siswa dan kurangnya pemahaman konsep-konsep matematika. Wahyudin (anggriamurti, 2008:2) menyatakan bahwa,

Salah satu kecenderungan yang menyebabkan siswa gagal menguasai dengan baik pokok-pokok bahasan dalam matematika yaitu karena siswa kurang menggunakan nilai yang logis dalam menyelesaikan soal atau persoalan matematika yang diberikan.

Banyak hal yang dapat dikaji untuk mengungkap masalah tersebut, diantaranya mungkin strategi pembelajarannya yang menyajikan aturanaturan yang kurang jelas. Masalah ini mungkin karena keterbatasan sarana belajar. Berbagai upaya telah ditempuh untuk meningkatkan kualitas pendidikan Indonesia, anatara lain, perbaikan kurikulum, penyediaan alat peraga dan perubahan metedo pembelajaran.

Tanggungjawab keberhasilan pengajaran di sekolah tentunya berada ditangan seorang pendidik. Artinya, seorang guru harus berupaya semaksimal mungkin untuk mengatur proses pembelajaran sehingga komponenkomponen yang diperlukan dalam pembelajaran tersebut dapat berinteraksi. Oleh karena itu, perlu diciptakan individu yang kreatif dan mampu menantang kehidupan.

Menurut UU SISDIKNAS NO. 20 Tahun bahwa,
$\begin{array}{ccc} & \text { "Pendidikan adalah usaha } \\ \text { sadar dan terencana untuk }\end{array}$ mewujudkan suasana belajar dan proses pembelajaran agar peserta didik secara aktif mengembangkan potensi dirinya untuk memiliki kekuatan, kecerdasan akhlak mulia serta keterampilan yang diperlukan dirinya dan masyarakat."

Realitas pembelajaran matematika di lapangan saat ini, pada umumnya belum berpusat pada siswa. Siswa di kelas tidak diperlakukan sebagai subjek belajar, guru dengan metode ceramahnya masih tetap mendominasi proses belajar mengajar. Inovasi pembelajaran masih jarang dilakukan sehingga komunikasi matematis siswa dengan siswa dan siswa dengan guru sangat sederhana.

Konsekuensinya menurut guru setempat kemampuan komunikasi matematis pada umumnya masih rendah dikarenakan pembelajaran matematika masih bersifat individual sehingga komunikasi antara siswa tidak optimal. Hal ini karena diakibatkan oleh guru yang kurang mampu menyampaikan materi dengan baik.

Salah satu alternative untuk mengatasi masalah diatas yaitu dengan menggunakan model pembelajaran Kooperatif Tipe Student Team Achievmen Division(STAD). Model pembelajaran ini 
menjanjikan kepada siswa untuk aktif dalam mengemukakan pendapat, berbagai pendapat dengan teman kelompoknya, bekerja sama, sehingga komunikasi antara siswa dengan guru dan siswa dengan siswa dapat berjalan dengan baik.

\section{Cooperative Learning Model STAD (Student Team Achievment Divison)}

Ruang kelas merupakan suatu tempat yang sangat baik untuk pelaksanaann kegiatan cooperative learning. Di dalam ruang kelas, para siswa dapat diberi kesempatan bekerja dalam kelompok-kelompok kecil untuk menyelesaikan atau memecahkan suatu masalah secara bersama. Model cooperative learning tampaknya akan dapat melatih para siswa untuk mendengarkan pendapat orang lain dan merangkum pendapat atau temuan-temuan dalam bentuk tulisan. Tugas-tugas kelompok akan dapat memicu para siswa untuk bekerja sama, saling membantu satu sama lain dalam mengintegrasikan pengetahuan baru dengan pengetahuan yang telah dimilikinya. Sehingga akan mengurangi bahkan menghilangkan rasa cemas terhadap matematika yang banyak dialami para siswa. cooperative learning juga telah sangat bermanfaat bagi model belajar ini dapat membuat siswa menerima siswa lain yang berkemampuan dan berlatar belakang yang berbeda.

Cooperative learning mencakap suatu kelompok kecil siswa yang bekerja sebagai sebuah tim untuk menyelesaikan sebuah masalah, menyelesaikan suatu tugas, atau mengerjakan sesuatu untuk mencapai tujuan bersama lainnya. Dari uraian di atas dapat dikemukakan bahwa cooperative learning adalah suatu model pembelajaran dengan sistem belajar dan bekerja dalam kelompok - kelompok kecil yang berjumlah $4-6$ orang secara kolaboratif sehingga dapat merangsang siswa lebih bergairah dalam belajar.

Beberapa model cooperative learning telah dikembangkan oleh para ahli. Beberapa model yang dikembangkan oleh para ahli diantaranya adalah Student Team Achievment Divison (STAD), Jigsaw, Grouf Investigation (GI), Rolating Trio Exchange, dan Group Resume. Dalam penelitian ini model yang dijadikan bahan penelitian adalah Student Team Achievment Divison (STAD).

Menurut Slavin

$(1995: 71)$

menyatakan bahwa,

"STAD (Student team achievement division) adalah guru menyampaikan materi, kemudian para siswa bergabung dalam kelompoknya yang terdiri atas empat atau lima orang untuk menjelaskan soal-soal yang diberikan oleh guru.

Setelah selesai mereka menyerahkan pekerjaannya secara tunggal untuk setiap kelompok kepada guru".

STAD (Studen Team Achievement Division), merupakan salah satu tipe pembelajaran kooperatip yang menekankan pada adanya aktivitas interaksi siswa untuk saling motivasi dan saling membantu utuk menguasai materi pelajaran guna mencapai prestasi yang optimal. Pada proses pembelajarannya, belajar kooperatip tipe STAD (Student Team Achievement Division) melalui lima tahapan, sebagai berikut.

1. Tahap penyajian materi

Pada tahap ini, guru memulai dengan menyampaikan indicator yang harus dicapai hari itu dan memotivasi rasa ingin tahu siswa tentang materi yang akan dipelajari.

2. Tahap kegiatan kelompok

Pada tahap ini siswa diberi lembar tugas sebagai bahan yang akan dipelajari. Dalam kerja kelompok siswa saling berbagi tugas, saling membantu memberikan penyelesaian agar semua anggota kelompok dapat emahami materi.

3. Tahap tes individual

Tujuan dari tahapan ini adalah untuk mengetahui sejauh mana keberhasilan 
siswa dalam belajar telah dicapai, melalui tes secara individual mengenai materi yang telah dibahas, pada tahapan ini tes individual dilakukan pada akhir pertemuan kedua dan ketiga, masing-masing selama 10 menit agar siswa dapat menunjukan apa yang telah dipelajari secara individu selama bekerja dalam kelompok. Skor perolehan individu ini di data dan diarsipkan untuk digunakan pada perhitungan perolehan skor kelompok.

4. Tahapan Perhitungan Skor

Perkembangan Individu

Tahap ini dihitung berdasarkan skor awal, didasarkan pada nilai evaluasi hasil belajar semester 1 (Satu). Skor nilai tes kemampuan individu tiap anggota kelompok dihitung untuk menentukan perolehan rata-rata skor individu tiap kelompok.

Nilai Perkembangan Individu (Sumbangan Untuk Nilai Kelompok)

\begin{tabular}{|l|l|c|}
\hline No & \multicolumn{1}{|c|}{ Nilai Tes Individu } & $\begin{array}{c}\text { Sumbangan } \\
\text { Untuk Nilai }\end{array}$ \\
\hline 1. & $\begin{array}{l}\text { Lebih dari 10 poin di bawah } \\
\text { nilai awal }\end{array}$ & 0 \\
2. & Antara 10 Poin dibawah nilai & 10 \\
3. & awal & 20 \\
Dengan nilai awal 1 sampai 10 & 30 \\
4 & Poin di atas nilai awal & 40 \\
5. & Lebih dari 10 poin di atas nilai & \\
\hline & awal & \\
\hline
\end{tabular}

5. Tahap Pemberian Penghargaan

Kelompok

Perhitungan skor kelompok dilakukan dengancara menjumlahkan masingmasing perkembangan skor individu dan hasilnya dibagi sesuai dengan anggota kelompok.

\begin{tabular}{|c|c|}
\hline $\begin{array}{c}\text { Nilai rata-rata } \\
\text { kelompok }\end{array}$ & Penghargaan \\
\hline 15 poin & Good team \\
20 poin & $\begin{array}{c}\text { Great team } \\
\text { Super team }\end{array}$ \\
\hline
\end{tabular}

\section{Komunikasi Matematis}

Menurut Kamus Besar Bahasa Indonesia (Nurhayatin, 2009:10) "Komunikasi adalah pengiriman dan penerimaan pesan antara dua orang atau lebih sehingga pesan yang dimaksud dapat dipahami”.

Rohmawati

(2008:10) mengemukakan bahwa, "Proses komunikasi pada hakekatnya adalah proses penyampaian pikiran atau perasaan oleh seseorang (komunikator) kepada orang lain (komunikan)".

Komunikasi secara umum dapat diartikan sebagai suatu cara untuk menyampaikan suatu pesan dari pembawa pesan ke penerima pesan untuk memberitahu, pendapat, atau perilaku baik langsung secara lisan, maupun tak langsung melalui media. Di dalam berkomunikasi tersebut harus dipikirkan bagaimana caranya agar pesan yang disampaikan seseorang itu dapat dipahami oleh orang lain. Untuk mengembangkan kemampuan berkomunikasi orang dapat menyampaikan dengan berbagai bahasa termasuk bahasa matematis sedangkan kemampuan matematis dapat diartikan sebagai suatu kemampuan siswa. Dalam menyampaikan sesuatu yang diketahuinya melalui peristiwa dialog atau hubungan yang terjadi di lingkungan kelas tempat terjadinya pengalaman siswa.

Pesan yang dialihkan berisi tentang materi matematis yang dipelajari siswa, misalnya berupa konsep, rumus atau strategi penyelesaian suatu masalah. Pihak yang terlibat dalam peristiwa komunikasi didalam kelas adalah guru dan siswa. Cara pengalihan pesannya dapat secara lisan maupun tertulis. Di dalam proses pembelajaran matematika dikelas, komunikasi gagasan matematis bisa berlangsung antara guru dengan siswa, antara buku dengan siswa dan antara siswa dengan siswa.

Sedangkan indicator kemampuan siswa dalam komunikasi matematis pada pembelajaran matematika menurut NCTM 
(1989: 214) dapat dilihat dari aspek-aspek berikut.

1. Kemampuan mengekpresikan ide-ide matematis melalui lisan, tertulis, dan mendemontrasikannya serta menggambarkannya secara visual.

2. Kemampuan memahami, menginterprestasikan dan mengevaluasi ide-ide matematis baik secara lisan maupun secara visual lainnya.

3. Kemampuan dalam menggunakan istilah-istilah, notasi-notasi matematis dan struktur-strukturnya untuk menyajikan ide, menggambarkan hubungan-hubungan dan modal-modal situasi.

Menurut Withim (1992: 23) menyatakan bahwa , "Kemampuan komunikasi menjadi penting ketika diskusi antar siswa dilakukan, sehingga siswa diharapkan mampu menyatakan dan berkerja sama.".

Dari uraian diatas, dapat disimpulkan bahwa kemampuan komunikasi matematis adalah kemampuan seseorang dalam mengomunikasikan ideide matematis. Kemampuan ini dapat ditingkatkan dengan menggunakan berbagai metode pembelajaran.

Proses pembelajaran matematika merupakan salah satu bagian dari keseluruhan proses pendidikan di sekolah maupun diperguruan tinggi . diharapkan dengan proses ini tujuan pendidikan akan dapat dicapai antara lain dalam bentuk terjadinya perubahan sikap, keterampilan, serta meningkatkan kemampuan berfikir siswa.

Secara umum kemampuankemampuan dasar diharapkan dapat digali bdan ditingkatkan melalui kegiatan belajar matematis adalah kemampuan komunikasi matematis yang ditujukan siswa dalam :

1. Merefleksikan dan menjelaskan pemikiran siswa mengenai ide dan hubungan matematis;
2. Mempormulasikan definisi matematis dan generalisasi;

3. Menyatakan ide matematis secara lisan dan tertulis;

4. Membaca wacana matematis dengan pemahaman;

5. Mengklarifikasi dan memperluas pertanyaan terhadap matematis yang dipelajarinya;

6. Menghargai keindahan dan kekuatan notasi matematis dan peranannya dalam pengembangan ide.

Adapun syarat-syarat keberhasilan komunikasi di antaranya sebagai berikut

1. Komunikator (pengirim pesan), merupakan sumber dan pengirim pesan. Kepercayaan penerima pesan pada komunikator dalam melakukan komunikasi sangat menentukan keberhasilan komunikasi.

2. Pesan yang disampaikan, keberhasilan komunikasi tergantung dari :

a. Daya tarik pesan itu sendiri;

b. Kesesuaian pesan dengan kebutuhan penerima pesan

c. Lingkup pengalaman yang sama antara pengirim dan penerima pesan tentang pesan tersebut;

d. Peranan pesan dalam memenuhi kebutuhan penerima pesan.

3. Komunikasi (penerima pesan), keberhasilan komunikasi tergantung dari:

a. Kemampuan komunikasi dalam menafsirkan pesan;

b. Komunikasi sadar bahwa pesan yang diterimanya memenuhi kebutuhannya;

c. Perhatian komunikasi terhadap pesan yang diterima.

4. Konteks, komunikasi berlangsung dalam lingkungan tertentu.

5. Sistem penyampaian, sistem penyampaian pesan berkaitan dengan metode dan media. Metode dan media yang sesuai dengan kondisi penerima 
pesan sangat menunjang keberhasilan komunikasi.

Jacob (2002:380), membagi aspek komunikasi kedalam lima bagian yaitu sebagai berikut.

1. Memprestasi

Memprestasi meliputi menunjukan kembali suatu ide atau masalah dalam bentuk baru, misalnya menerjemahkan masalah kata dalam suatu model konkret dalam gambar, menyajikan persoalan atau masalah kedalam model matematika, gerafik tabel, atau sejumlah kalimat (Simbol tertulis).

2. Mendengar

Mendengarkan dengan teliti terhadap komentar dan pertanyaan baik dari guru maupun siswa lain kemudian dapat bermanfaat dalam mengkontruksi pengetahuan matematis yang lebih lengkap atau strategi yang lebih efektif.

3. Membaca

Melihat serta memahami isi apa yang ditulis, lebih menekankan kepada membaca literature siswa dan secara bertahap meningkat menggunakan text books matematik. Siswa menggunakan text books matematikanya sebagai suatu sumber informasi dan ide-ide, tidak hanya sebagai suatu sumber pekerjaan rumah.

4. Berdiskusi

Diskusi kelas bertujuan untuk membuat siswa dalam mempraktikan komunikasi lisan. Diskusi merupakan pertemuan ilmiah untuk bertukar pikiran, saling tukar-menukar informasi mengenai suatu masalah, dan memberikan saran dalam memecahkan masalah.

5. Menulis

Menulis dalam belajar matematika lebih ditekankan pada pengekspresian ide-ide matematik yang berkenaan dengan dua pendekatan yaitu pembelajaran untuk menulis dan menulis untuk belajar. Menulis untuk belajar mencakup dorongan untuk bagaimana menulis dapat digabungkan ke pembelajaran matematik.

Secara garis besar komunikasi dapat dibagi menjadi dua bagian yaitu komunikasi verbal dan komunikasi non verbal. Komunikasi verbal adalah komunikasi dengan menggunakan bahasa, baik lisan maupun tulisan . sedangkan komunikasi non verbal adalah komunikasi yang menggunakan isyarat, gerak-gerik, lambing, dan sebagainya.

1. Komunikasi Lisan

Komunikasi lisan adalah kemampuan siswa dalam menyampaikan gagasan dan ide dalam suatu masalah matematika secara lisan. Untuk melihat kemampuan komunikasi secara lisan , dapat digunakan indicator menurut Djumur (Rohmawati,2008: 21) sebagai berikut.

a. Indikator komunikasi lisan dalam representasi:

1) Siswa dapat menyajikan penyelesaian dari suatu masalah;

2) Siswa dapat memilih cara yang tepat untuk menyelesaikan jawaban dari suatu masalah;

3) Menggunakan tabel, gambar, model, dan lain-lain untuk menyampaikan jawaban dari suatu masalah;

4) Memberikan saran atau pendapat lain untuk menjawab dari suatu permasalahan;

5) Merespon suatu pertanyaan atau persoalan dari audiens dalam bentuk argument yang menyakinkan;

6) Mampu menginterpretasikan dan mengevaluasi ide-ide, simbol istilah serta informasi matematika;

7) Mengungkapkan lambing, notasi dan persamaan secara cepat;

8) Mengorganisasi dan menghimpun pemikiran matematika melalui komunikasi; 
9) Mengkomunikasikan pemikiran matematika secara berkaitan dan jelas kepada teman, guru dan lainnya.

b. Indikator komunikasi lisan dalam diskusi:

1) Siswa ikut menyampaikan pendapat tentang masalah yang dibahas;

2) Siswa berpartisifasi aktif dalam menanggapi pendapat yang diberikan siswa lain;

3) Siswa mau mengajukan pertanyaan ketika ada sesuatu yang tidak dimengerti;

4) Mendengarkan secara serius ketika siswa lain mengemukakan pendapat;

5) Menganalisis dan mengevaluasi pemikiran dan strategi matematika orang lain.

2. Komunikasi Tertulis

Komunikasi tertulis merupakan kemampuan siswa dalam menyampaikan gagasan dan ide dari suatu permasalahan secara tertulis. Indikator untuk melihat kemampuan komunikasi tertulis dikemukakan oleh Ross (Rohmawati. 2008: 22) adalah :

a. Menggambarkan situasi masalah dan menyatakan solusi masalah menggunakan gambar, bangun, tabel, dan secara aljabar;

b. Menyatakan hasil dalam bentuk tertulis;

c. Menggunakan representasi menyeluruh untuk menyatakan konsep matematika dan solusinya;

d. Membuat situasi matematika dengan menyediakan ide dan keterangan dalam bentuk tertulis;

e. Menggunakan bahasa matematika dan symbol secara tepat.

Komunikasi yang digunakan berdasarkan KTSP (Kurikulum Tingkat Satuan Pendidikan) Sekolah Dasar, yaitu mengkomunikasikan gagasan dengan symbol, table, diagram, atau media lain untuk memperjelas keadaan atau masalah.

\section{Metodologi Penelitian}

Metode penelitian yang digunakan adalah penelitian tindakan kelas dengan menggunakan model pembelajaran Student Teams Achievment Divison (STAD). Penelitian tindakan kelas (PTK) sudah tidak asing lagi dan ramai dibicarakan dalam dunia pendidikan. Menurut Aqib (2006: 12) bahwa, Penelitian tindakan kelas (PTK) terdiri dari tiga kata, maka ada tiga pengertian pula yang dapat diterangkan.

1. Penelitian yaitu kegiatan mencermati suatu objek, menggunakan aturan metodologi tertentu untuk memperoleh data atau informasi yang bermanfaat untuk meningkatkan mutu dari suatu hal yang menarik minat dan penting bagi peneliti.

2. Tindakan yaitu suatu gerak kegiatan yang sengaja dilakukan dengan tujuan tertentu yang dalam penelitian ini berbentuk rangkaian atau siklus kegiatan.

3. Kelas yaitu sekelompok siswa yang dalam kurun waktu bersamaan menerima pelajaran yang sama dari seorang guru.

Pelaksanaan penelitian tindakan kelas merupakan bentuk kegiatan yang bertujuan memperbaiki kondisi praktek pembelajaran dilakukan. Prosedur pelaksanaan penelitian tindakan kelas ini dalam pengumpulan datanya dilakukan dengan langkah-langkah berikut.

1. Identifikasi masalah

2. Perencanaan atau persiapan tindakan. Adapun perencanaan atau persiapan tindakan pada penelitian ini adalah sebagai berikut.

Pembuatan silabus dan perencanaan pengajaran yang sudah dikonsultasikan dengan dosen pembimbing dan guru matematika ditempat penelitian.

a. Pembuatan perangkat tes.

b. Pembuatan angket pendapat siswa.

3. Pelaksanaan tindakan.
a. Melaksanakan
pembelajaran dengan
menggunakan 
pembelajaran Student Teams Achievment Divison (STAD).

b. Melaksanakan tes pormatif setiap akhir siklus dilaksanakan.

c. Melaksanakan tes subsumatif setelah ketiga siklus dilaksanakan.

d. Membagikan angket pada akhir pembelajaran.

4. Evaluasi dan monitoring

5. Refleksi dan analisis

Pada bagian refleksi dilakukan analisis data mengena proses, masalah, dan hambatan yang dijumpai dan dilanjutkan dengan menyusun rencana perbaikan pada siklus (daur) berikutnya dikelas oleh guru yang sama.

Adapun langkah-langkah dalam tindakan refleksi yaitu :

a. Mengidentifikasi permasalahan yang ada dan belum terpecahkan atau yang muncul selama tindakan pembelajaran berlangsung;

b. Menganalisis dan merinci tindakan pembelajaran yang telah dilaksanakan berdasarkan kendala-kendala yang dijumpai guru;

c. Menentukan tindakan berdasarkan hasil analisis tindakan.

\section{Pembahasan Hasil Penelitian}

Berdasarkan hasil tes yang dilakukan setiap siklus (pertemuan) dan tes subsumatif terdapat peningkatan kemampuan komunikasi matematis siswa. Terlihat pada tabel 4.1 dan gambar 4.1 pada setiap siklus terdapat peningkatan komunikasi matematis siswa. Hal ini ditunjukan selama pembelajaran berlangsung, siswa pada setiap pertemuannya terdapat sebuah perubahan pada saat mengikuti kegiatan pembelajaran. Siswa dapat mengungkapkan atau merefleksikan fikirannya lewat tulisan. Dengan menulis siswa secara aktif membangun hubungan antara yang ia pelajari dengan apa yang sudah ia ketahui dengan menghubungkan berupa penggunaan simbol, gambar, dan tabel pada saat proses belajar mengajar berlangsung. Dapat disimpulkan bahwa, kemampuan komunikasi matematis siswa dengan menggunakan model pembelajaran kooferatif tipe Student Teams Achievement Division (STAD) dapat meningkat.

Berdasarkan hasil dari uji $\mathrm{z}$ dapat disimpulkan bahwa, pokok bahasan pecahan yang pembelajarannya menggunakan model kooferatif tipe Student Teams Achievement Division (STAD) dapat dipahami dengan baik. Terbukti dari hasil perhitungan nilai $\mathrm{z}$ diperoleh $\mathrm{Z}$ hitung $=1,5$ terletak didalam interval $\left(-Z_{0,4900}\right.$ s.d $Z_{0,4900)}$.maka hipotesis diterima.

Berdasarkan hasil angket yang diberikan pada bagian akhir penelitian diperoleh data bahwa angket pendapat siswa berada pada interval $3<\mathrm{Xt} \leq 5$ $\{$ jumlah total jawaban $(\mathrm{Xt}=4,0)$. Sehingga dapat disimpulkan bahwa, pendapat atau tanggapan siswa terhadap penerapan model pembelajaran kooperatif tipe Student Team Achievement Division (STAD) pada pokok bahasan pecahan adalah positif.

Setelah dilakukan penelitian, dirasakan ada beberapa kelebihan dalam proses pembelajaran dengan menggunakan model pembelajaran kooperatif tipe Student Team Achievement Division (STAD). Diantaranya:

1. Siswa bekerja sama dalam mencapai tujuan dengan mengjungjung tinggi norma-norma kelonpok;

2. Siswa aktif membantu dan memotivasi semangat untuk berhasil bersama;

3. Interaksi antar siswa seiring dengan peningkatan kemampuan mereka dalam berpendapat.

\section{Penutup}

Berdasarkan hasil deskripsi data dan pembahasan maka diperoleh simpulan sebagai berikut. 
a. Penggunaan model pembelajaran kooperaif tipe Student Team Achievement Division (STAD) dapat meningkatkan kemampuan komunikasi matematis siswa. Hal ini didukung dengan hasil perhitungan indeks gain yang meningkat mulai dari 0,2 (rendah) sampai dengan 0,4 (cukup).

b. Materi pecahan dapat dipahami dengan baik dengan menggunakan model pembelajaran kooperatif tipe Student Team Achievement Division (STAD). Hal tersebut didukung dengan hasil perhitungan uji $\mathrm{Z}$ hitung $=1,5$ dan $Z$ daftar $=2,33$ dengan taraf kesalahan $a \neq 1 \%$. Ternyata $Z$ hitung berada di luar interval $\mathrm{Z}$ daftar yaitu 2,33 sampai dengan 2,33.

c. Tanggapan siswa positif terhadap model pembelajaran kooperatif tipe Student Team Achievement Division (STAD). Hal tersebut di dukung dengan hasil perolehan skor rata-rata angket siswa yaitu 4,0 termasuk kriteria positif.

Berdasarkan simpulan diatas, penulis mengajukan saran-saran, sebagai berikut.

a. Diharapkan siswa dapat memperoleh pengalaman secara langsung belajar matematika dengan menggunakan model pembelajaran kooperatif tipe Student Team Achievement Division (STAD) dan dapat meningkatkan kemampuan komunikasi matematis, serta mendorong mereka lebih aktif dan kreatif dalam menyelesaikan suatu permasalahan yang berkaitan dengan permasalahan matematis.

b. Diharapkan guru dapat menggunakan model pembelajaran kooperatif tipe Student Team Achievement Division (STAD) sebagai bahan masukan alternative pembelajaran matematika.

c. Diharapkan sekolah dapat memberikan masukan atau motivasi mengenai strategi pembelajaran disamping itu diharapkan sekolah memberikan pelatihan kepada guru mengenai model-model pembelajaran.

\section{Daftar Pustaka}

Anggriamurti, A. (2008). Pembelajaran Transformasi Geometri dengan pendekatan Kontruktivisme untuk Meningkatkan Penalaran Logis. Skripsi pada Jurusan Matematika FPMIPA UPI Bandung: Tidak diterbitkan.

Aqib, Z. (2006). Penelitian Tindakan Kelas. Bandung: CV Rama Widya.

Dewi. (2005). Menerapkan Model Pembelajaran Kooperatif Tipe Student Team Achievement Division (STAD)pada Materi Diferensial. Skripsi STKIP Sebelas April Sumedang: Tidak dipublikasikan.

Hamalik, O. (1994). Kurikulum dan Pembelajaran. Bandung: Bmi Aksara.

Jacob, C. (2002). Matematika Sebagai Komunikasi. Malang: Universitas IV Malang.

Karso. (1993). Dasar-Dasar Pendidikan MIPA. Jakarta: DEPDIKNAS.

Kholik, A. (2008). Epektifitas Penggunaan Pendekatan Kontruktivisme untuk Meningkatkan Kemampuan Penalaran dan Prestasi Belajar Matematika. STKIP Sebelas April Sumedang: Tindak diterbitkan.

NTCM. (1989). Curiculum and Evaluation Standard for School Mathematic. Reston, VA: NTCM.

Nurhayatin, T. (2009). Studi Perbandingan kemampuan komunikasi 


$$
\begin{aligned}
& \begin{array}{l}
\text { matematika pada Siswa Tinggi, } \\
\text { Sedang, Rendah }
\end{array} \text { dengan } \\
& \text { Menggunakan Snow ball Trowing. } \\
& \text { Skripsi STKIP Sebelas April } \\
& \text { Sumedang: Tidak diterbitkan. }
\end{aligned}
$$

Rohmawati, E. (2008). Pembelajaran dengan Memberikan Tugas Bentuk Supritmen Dlaam Upaya Meningkatkan Komunikasi Matematika . Skripsi STKIP Sebelas April Sumedang: Tidak diterbitkan.

Slameto. (2003). Belajar dan FaktorFaktor yang Mempengaruhinya. Jakarta: Rineka Cipta.

Slavin, R. (1995). Cooverative Learning Theory. Research and Practise, Second Edition. Boston: Ailyn and Bacon.

Suherman, E dkk. (2001). Ringkasan Materi Perkuliahan Strategi Pembelajaran Matematika. Bandung: Jurdimat FPMIPA UPI.

Sukmara, D. (2007). Implementasi Life Skill dalam KTSP. Bandung: Mugni Sejahtera.

Tim MKPBN. (2001). Strategi Pembelajaran Kontemporer. Bandung: UPI.

Undang-Undang Republik Indonesia. (2003). Sistem Pendidikan Nasional. Jakarta: CV. Mini Jaya Abadi.

Within. (1992). Mathematic Task Centre Proffesional Development and Problem Solving. In J Wakefield and $L \quad$ Velardi $(E d)$. Celebrating Mathematics Learning, Melbourne The Mathematical Asocciation of Victoria 